\title{
Characterization of SARS-CoV-2 East Java isolate, Indonesia
}

\section{[version 1; peer review: 2 approved, 1 approved with}

\section{reservations]}

\author{
Fedik Abdul Rantam (iD1,2, Cita Rosita Sigit Prakoeswa(iD3, Damayanti Tinduh(iD4, \\ Jusak Nugraha (iD) 5elen Susilowati ${ }^{1}$, Andi Yasmin Wijaya (iD6, \\ Ni Nyoman Tri Puspaningsih7, Dwiyanti Puspitasari8, Dominicus Husada8, \\ Neneng Dewi Kurniati ${ }^{9}$, Aryati Aryati $^{5}$
}

\footnotetext{
${ }^{1}$ Research Center for Vaccine Technology and Development, Institute of Tropical Disease, Airlangga University, Surabaya, East Java, 60132, Indonesia

${ }^{2}$ Virology and Immunology Laboratory, Department of Microbiology, Faculty of Veterinary Medicine, Airlangga University, Surabaya, East Java, 60132, Indonesia

${ }^{3}$ Professioal Education and Research, Dr. Soetomo General Academic Hospital, Faculty of Medicine, Airlangga University, Surabaya, East Java, 60132, Indonesia

${ }^{4}$ Research and Development Board, Dr. Soetomo General Hospital, Surabaya, East Java, 60132, Indonesia

${ }^{5}$ Clinical Pathology Department, Dr. Soetomo General Hospital, Faculty of Medicine, Airlangga University, Surabaya, East Java, 60132, Indonesia

${ }^{6}$ Faculty of Medicine, Airlangga University, Surabaya, East Java, 60132, Indonesia

${ }^{7}$ Bioresource Engineering Group in Research Center for Bio-Molecule Engineering (BIOME), Airlangga University, Surabaya, East Java, 60132, Indonesia

8Pediatrics Department, Dr. Soetomo General Hospital, Surabaya, East Java, 60132, Indonesia

${ }^{9}$ Clinical Microbiology Department, Dr. Soetomo General Hospital, Surabaya, East Java, 60132, Indonesia
}

V1 First published: 16 Jun 2021, 10:480

https://doi.org/10.12688/f1000research.53137.1

Latest published: 16 Jun 2021, 10:480

https://doi.org/10.12688/f1000research.53137.1

\section{Abstract}

Background: Incidents of SARS-CoV-2 in East Java increased steadily, and it became the second epicenter in Indonesia. The COVID-19 pandemic caused a dire multisectoral crisis all around the world. This study investigates and characterizes local isolates from East Java, Indonesia.

Methods: There were 54 patients suspected with SARS-COV-2 infection and 27 patients were COVID-19 positive. Virus isolates were obtained from COVID-19 inpatients' nasopharyngeal swabs at the Dr Soetomo Teaching Hospital, Surabaya. There were only three isolates (\#6, \#11, \#35) with good growth

characteristics. Serial blind passage and cytopathic effect observation in the Vero E6 cell line were performed for virus isolation. Confirmation of the SARS-CoV-2 infection was proven by means of reverse transcriptase-polymerase chain reactions using SARS-CoV-2 specific primers, scanning electron microscopy, and scanning

\section{Open Peer Review \\ Approval Status $\checkmark$ ? 12 23 \\ version 1 ? 16 Jun 2021 view view view \\ 1. Aulanni'am Aulanni'am (D), Universitas Brawijaya, Malang, Indonesia \\ 2. Lidia Audrey Rocha Valadas ID, University of Buenos Aires, Buenos Aires, Argentina \\ 3. Marina Derkho, South Ural State Agrarian University, Troitsk, Russian Federation} Any reports and responses or comments on the 
transmission electron microscopy examination. Whole genome sequencing was performed using ARTIC protocol. Furthermore, SARSCoV-2 characterization was identified through a western blot using rabbit serum immunized with inactive SARS-CoV-2 vaccine and human natural COVID-19 infection serum.

Results: Spike gene analysis of three samples $(\# 6, \# 11, \# 35)$ found that the D614G mutation was detected in all isolates, although one isolate exhibited the D215Y and E484D mutation. Based on whole genome analysis, those three isolates were included in clade 20A, and two isolates were included in lineage B.1.6 with one isolate belongs to lineage B.1.4.7.

Conclusion: Based on molecular characterization and immunogenicity of SARS-CoV-2 East Java, Indonesia showed high titer and it has mutation in some regions.

\section{Keywords}

growth properties, COVID-19, SARS-CoV-2, virus isolation, infectious disease

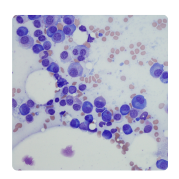

This article is included in the Cell \& Molecular

Biology gateway.

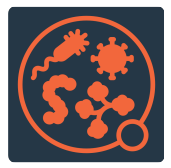

This article is included in the Pathogens

gateway.

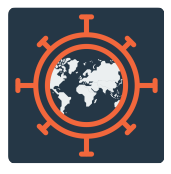

This article is included in the Emerging Diseases

and Outbreaks gateway.

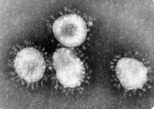

This article is included in the Coronavirus

collection. article can be found at the end of the article. 
Corresponding author: Fedik Abdul Rantam (fedik-a-r@fkh.unair.ac.id)

Author roles: Rantam FA: Conceptualization, Data Curation, Formal Analysis, Funding Acquisition, Investigation, Methodology, Project Administration, Resources, Software, Supervision, Validation, Visualization, Writing - Original Draft Preparation, Writing - Review \& Editing; Prakoeswa CRS: Conceptualization, Formal Analysis, Funding Acquisition, Investigation, Methodology, Resources, Supervision, Validation, Visualization, Writing - Original Draft Preparation, Writing - Review \& Editing; Tinduh D: Conceptualization, Funding Acquisition, Investigation, Methodology, Supervision, Validation, Visualization, Writing - Original Draft Preparation, Writing - Review \& Editing; Nugraha J: Conceptualization, Data Curation, Formal Analysis, Funding Acquisition, Investigation, Methodology, Supervision, Validation, Visualization, Writing - Original Draft Preparation, Writing - Review \& Editing; Susilowati H: Conceptualization, Data Curation, Formal Analysis, Funding Acquisition, Investigation, Methodology, Project Administration, Resources, Software, Supervision, Validation, Visualization, Writing - Original Draft Preparation, Writing - Review \& Editing; Wijaya AY: Conceptualization, Data Curation, Formal Analysis, Funding Acquisition, Investigation, Methodology, Project Administration, Resources, Software, Supervision, Validation, Visualization, Writing - Original Draft Preparation, Writing - Review \& Editing; Puspaningsih NNT: Conceptualization, Data Curation, Formal Analysis, Funding Acquisition, Investigation, Methodology, Supervision, Validation, Visualization, Writing - Original Draft Preparation, Writing - Review \& Editing; Puspitasari D: Conceptualization, Data Curation, Formal Analysis, Funding Acquisition, Investigation, Methodology, Supervision, Validation, Visualization, Writing - Original Draft Preparation, Writing - Review \& Editing; Husada D: Conceptualization, Data Curation, Formal Analysis, Funding Acquisition, Investigation, Methodology, Supervision, Validation, Visualization, Writing - Original Draft Preparation, Writing - Review \& Editing; Kurniati ND: Conceptualization, Data Curation, Formal Analysis, Funding Acquisition, Investigation, Methodology, Resources, Validation, Visualization, Writing - Original Draft Preparation, Writing - Review \& Editing; Aryati A: Conceptualization, Data Curation, Formal Analysis, Funding Acquisition, Investigation, Methodology, Supervision, Validation, Visualization, Writing - Original Draft Preparation, Writing - Review \& Editing

Competing interests: No competing interests were disclosed.

Grant information: This study obtained a research grant from the Ministry of Research and Technology, Republic of Indonesia (Kemenristek/BRIN) and Lembaga Pengelola Dana Keuangan (LPDP), Ministry of Finance, Republic of Indonesia. The funders had no role in study design, data collection and analysis, decision to publish, or preparation of the manuscript.

Copyright: (c) 2021 Rantam FA et al. This is an open access article distributed under the terms of the Creative Commons Attribution License, which permits unrestricted use, distribution, and reproduction in any medium, provided the original work is properly cited.

How to cite this article: Rantam FA, Prakoeswa CRS, Tinduh D et al. Characterization of SARS-CoV-2 East Java isolate, Indonesia [version 1; peer review: 2 approved, 1 approved with reservations] F1000Research 2021, 10:480 https://doi.org/10.12688/f1000research.53137.1

First published: 16 Jun 2021, 10:480 https://doi.org/10.12688/f1000research.53137.1 


\section{Introduction}

Coronaviruses are an enveloped positive single-stranded ribonucleic acid (RNA) virus that can infect several species via zoonotic transmission. ${ }^{1,2}$ The coronavirus viral particle is a heterogenous, spherical, crown shaped viral particle with a diameter ranging from $80-160 \mathrm{~nm}^{2}$ Severe acute respiratory syndrome coronavirus 2 (SARS-CoV-2) possesses several main structural proteins including envelope, membrane, nucleoprotein, and spike protein. ${ }^{3}$ Spike protein facilitates the SARS-CoV-2 infection interacting with the human angiotensin-converting enzyme-2 (ACE-2) protein, which acts as a receptor, and it is expressed in various tissues in the body. ${ }^{4}$ This abundant presence of a virus receptor could be responsible for its rapid spread of infection. In addition, spike protein as the main protein of interest such as envelope, membrane, and nucleoprotein could also have an immunogenic capability. ${ }^{3}$ Worldwide genomic surveillance has proven that the spike protein exhibits a tendency to have multiple sites of mutation.

Several major mutations of concern in SARS-CoV-2 target the spike protein such as in the UK (lineage B.1.1.7), South Africa (B.1.351), and Brazil (lineage P.1), and caused concern as these mutations were responsible for enhancing SARS-CoV-2 infection morbidity and resistance of serum neutralization. ${ }^{5-7}$ However, these mutations were not proven to correlate with COVID-19 severity and mortality.

The SARS-CoV-2 infection caused the Coronavirus Disease 2019 (COVID-19) that was first reported in Wuhan, China, in December, 2019 and escalated quickly until it was declared a global pandemic by the World Health Organization (WHO) in March 2020. ${ }^{8,9}$ SARS-CoV-2 is spread through droplets and aerosol-mediated infection that relate to COVID19 primary symptoms of respiratory complaints that vary from mild symptoms to dire acute respiratory distress syndrome (ARDS). ${ }^{10}$ However, in a recent development, it has been reported that the SARS-CoV-2 infection can spread from the respiratory tract port of entry to the whole human body, and can cause various clinical manifestations, from gastrointestinal symptoms (diarrhea, nausea, and vomiting), neurological symptoms (anosmia and decrease of taste senses), ophthalmological symptoms (conjunctivitis), nephrological symptoms (acute kidney injury), hypercoagulability state, and systemic viral sepsis. ${ }^{11,12}$

Indonesia, one of the tropical countries in Southeast Asia, began to detect and report its patient zero on March 2, 2020, in Jakarta. After the first two confirmed cases were declared positive for infection of SARS-CoV-2, the infection began to spread across the Indonesian archipelago. ${ }^{13,14}$ In May, 2020, the incidence of SARS-CoV-2 increased steadily in Surabaya, making it the second epicenter in Indonesia after Jakarta. ${ }^{15}$

Indonesia is the fourth most populated country in the world to be affected by the COVID-19 pandemic, and various areas of national concern have been impacted, including economics, politics, and human welfare ${ }^{16,17}$ Researchers around the world are now racing against SARS-CoV-2, aiming to control its impact with a holistic approach. ${ }^{18}$ Development and evaluation of COVID-19 diagnostic tools, clinical management, and vaccine candidates are known to be global priorities, especially the protection of healthcare providers as frontline workers in pandemic management and mitigation, as they are more exposed to COVID-19. ${ }^{19,20}$ As SARS-CoV-2 spread around the globe, it was revealed that, based on the reported SARS-CoV-2 whole genome database, SARS-CoV-2 had already undergone several genetic mutations from its ancestor, generating evidence for distinct lineages by the summer of $2020 .{ }^{8}$ Therefore, it has been suggested that isolation and characterization of SARS-CoV-2 strains from various places is required to ensure a compatible tailor-made SARS-CoV-2 management plan for specific conditions. ${ }^{20,21}$ SARS-CoV-2 genomes that have been reported in Indonesia consist of predominantly lineage B.1 based on the GISAID SARS-CoV-2 genome database and they are divergent from the Wuhan isolate. $^{21}$

It is reported that at the population level, there is relatively insufficient herd immunity to drive significant mutation, and there are several spike mutations that increase virus transmission without changes in clinical significance such as D614G. Moreover, an immune system exposed to a variant of SARS-CoV-2 can be active also on other variants, given the generation of polyclonal antibodies for multiple epitopes. ${ }^{22,23}$

This is the first report characterizing the SARS-CoV-2 East Java, Indonesia local isolates. This study collected SARSCoV-2 material from three virus isolates and infected Vero E6 cells. Furthermore, this study aims to investigate the characterization of SARS-CoV-2 East Java, Indonesia local isolates.

\section{Methods}

Subject characteristics

Subject data was retrieved from Dr Soetomo General Hospital medical records. The first subject, (\#35 subject), was a local transmission case of a 49 -year-old man with a normal body mass index $\left(22.9 \mathrm{~kg} / \mathrm{m}^{2}\right)$, who was discharged on the 15th day of hospital care. The second subject, (\#6 subject), was a local transmission case of a 38-year-old woman with 
an overweight body mass index $\left(25.2 \mathrm{~kg} / \mathrm{m}^{2}\right)$ and who rapidly tested positive for $\mathrm{IgG}$ with IgM antibodies. Subject \#6 was admitted to inpatient care and deteriorated until being declared brain dead after six days of hospitalization due to respiratory failure. The third subject, (\#11 subject), was a local transmission case of a 64-year-old woman with a normal body mass index $\left(19.5 \mathrm{~kg} / \mathrm{m}^{2}\right)$ and a history of breast cancer, and was in remission. Subject \#11 was discharged after 26 days of hospitalization.

\section{Specimen collection}

There were 54 patients suspected with SARS-COV-2 infection and of these 27 patients were diagnosed COVID-19 positive during March to June 2020. A SARS-CoV-2 sample source was retrieved from COVID-19 confirmed inpatients in the Dr Soetomo General Hospital and three isolates originating from three individual subjects from Surabaya, Indonesia were obtained. Each subject was asked for informed consent. A nasopharyngeal swab was performed to obtain a SARS-CoV-2 sample using a sterile cotton swab. The sample cotton swab was then submerged in virus transport medium (VTM) containing a sterile filtered solution of Minimum Essential Media (MEM) (Gibco, USA), 1x penicillin-streptomycin (Gibco, USA), and 1x amphotericin B (Gibco, USA) as reported before. ${ }^{24}$ The sample was then immediately transferred, in a $4^{\circ} \mathrm{C}$ cool box containing an icepack, to the Research Center for Vaccine Technology and Development, Institute of Tropical Diseases Laboratory, Biosafety Level-3 (BSL-3) facility in Universitas Airlangga, Surabaya, East Java, Indonesia. ${ }^{25}$

\section{SARS-CoV-2 isolation}

There were only three samples from subjects \#6, \#11, \#35 with good growth characteristics that provided isolates. Serial blind passage and cytopathic effect observation in the Vero E6 cell line were performed for virus isolation. The virus isolation that was performed in the Vero E6 cell line (ATCC, USA) was seeded on a T25 flask (Corning, USA) with a $2 \times 10^{6}$ cell count and cultured with a MEM (Gibco, USA), supplemented with $10 \%$ Fetal Bovine Serum (FBS) (Gibco, USA) until it reached $80 \%$ confluency $\left(37^{\circ} \mathrm{C}\right.$ and $5 \% \mathrm{CO}_{2}$ ), (Figure 1 ), by introducing a $1 \mathrm{ml}$ sample of VTM to the Vero E6 cell line culture for a one-hour incubation. After incubation, $4 \mathrm{ml}$ of fresh MEM (Gibco, USA), supplemented with $10 \%$ FBS (Gibco, USA) were added. The cell was labeled as inoculation culture and observed daily through a phase contrast inverted microscope TMS (Nikon, Japan). After three days of inoculation, blind passage was performed to a fresh monolayer Vero E6 cell culture by introducing a $1 \mathrm{ml}$ supernatant medium from infected cells with a one-hour incubation before adding $4 \mathrm{ml}$ of fresh MEM supplemented with 10\% FBS medium. Viral growth was analyzed using cytopathogenic effect (CPE) and plaque forming unit (PFU) assay. TCID50 evaluation of \#35 isolate through plaque forming
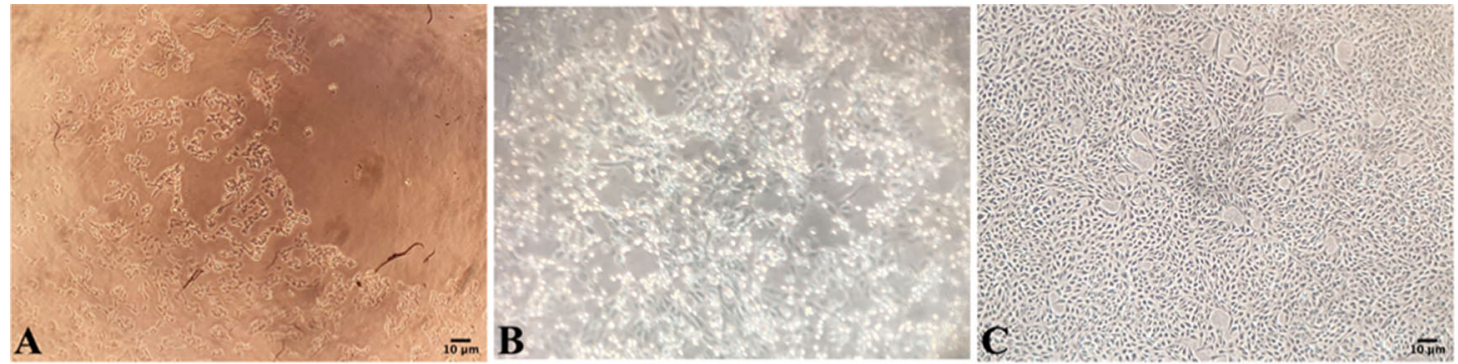

D
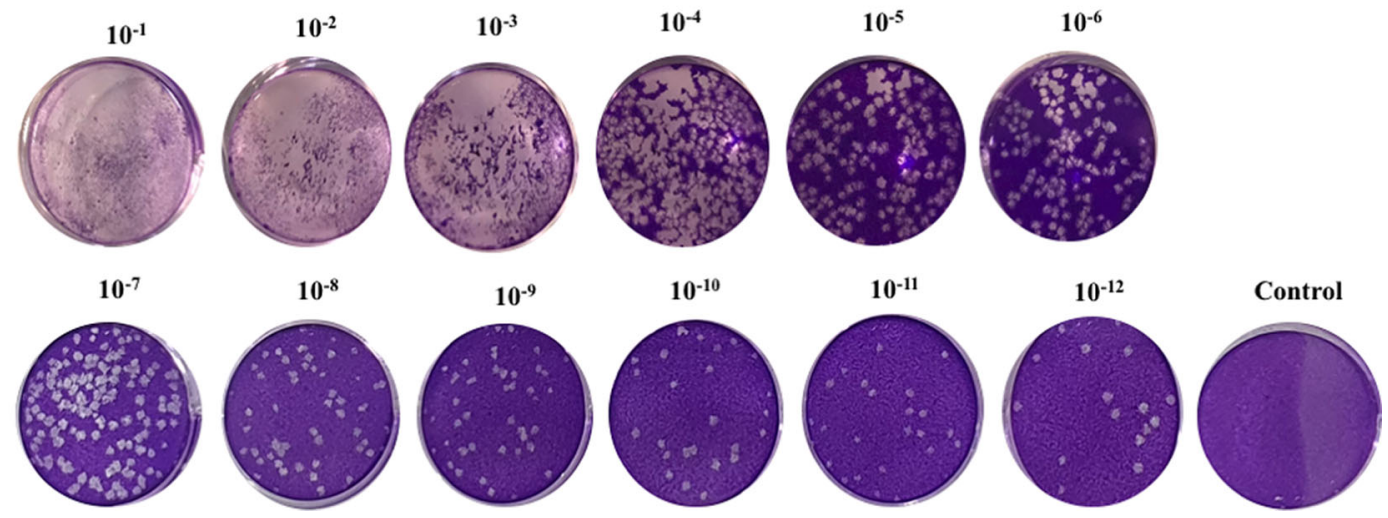

Figure 1. (A) Cytopathic effect of infected Vero E6 cell in third blind passage on the eighth day post passage (40 $\times$ magnification); (B) Cytopathic effect of infected Vero E6 cell in 15th blind passage on second day post passage (40 $\times$ magnification); (C) Uninfected Vero E6 cell in $\mathbf{4 0} \times$ magnification; (D) Plaque-Forming Unit (PFU) evaluation (Nikon TMS inverted microscope, Japan). 
assay and Reed and Muench method was as follows: $\log 1050 \%$ end point dilution $=\log 10$ of dilution showing a mortality next above $50 \%$ - (difference of logarithms $\times$ logarithm of dilution factor). Generally, the following formula is used to calculate "difference of logarithms" (difference of logarithms is also known as "proportionate distance" or "interpolated value"): Difference of logarithms $=$ [(mortality at dilution next above 50\%)-50\%] $/$ [(mortality next above 50\%) (mortality next below 50\%)]. ${ }^{26}$

\section{SARS-CoV-2 morphology}

The entire electron microscopy sample preparation was performed in a biosafety class II, type A2 biosafety cabinet (Nuaire, USA). SARS-CoV-2 morphology was assessed using a scanning electron microscope (SEM) and a scanning transmission electron microscope (STEM). Sample preparation for SEM was performed by collecting and filtering $1 \mathrm{ml}$ of UV-inactivated infected medium from the virus culture during the occurrence of cytopathic effect through a $1 \mu \mathrm{m}$ pore syringe nitrocellulose filter (Merck, USA) to trap the virus. Fixation, Periodic Acid-Schiff (PAS), was performed by filtering $2 \mathrm{ml}$ of $2 \%$ glutaraldehyde (Serva, USA) through the virus-entrapped syringe filter and incubating at $4^{\circ} \mathrm{C}$ for four hours. The fixated syringe filter then went through a dehydration process with cold ethanol (Merck, USA), at a gradient of $50 \%, 70 \%, 85 \%, 95 \%$ ethanol, and absolute ethanol with 15 minutes of incubation for each sequential dehydration process. Glutaraldehyde fixation and 50-75\% ethanol dehydration sequences were performed using a $4{ }^{\circ} \mathrm{C}$ refrigerator in an airtight container. The $85 \%$ and absolute ethanol dehydration processes were carried out at room temperature. The nitrocellulose membrane filter was then extracted from the syringe filter using pliers and air-dried in a biosafety cabinet overnight. A FEI Quanta 650 FEG (FEI, USA) electron microscope in low vacuum SEM mode $(80 \mathrm{~Pa} ; 10 \mathrm{kV})$ at $80,000 \times$ magnification and Modular Automated Processing System (MAPS) software version 3.14.11 (ThermoFisher Scientific, Waltham, Massachusetts, United States) was used for sample observation.

STEM sample preparation was performed by collecting and pipetting 50 $\mu \mathrm{l}$ UV-inactivated infected mediums from virus culture during the occurrence of cytopathic effect to parafilm. Immobilization of a SARS-CoV-2 viral particle was conducted on a formvar (SPI-chem, USA) coated copper electron microscope grid (EMS, USA). Formvar grid coating was performed according to UK standards for microbiology investigation protocols. ${ }^{27}$ The formvar-coated grid was pushed to an infected medium droplet on parafilm and incubated for 20 minutes. Excess infected medium was absorbed by filter paper, air-dried, and fixated with $2 \%$ glutaraldehyde in an airtight container $\left(4^{\circ} \mathrm{C}\right.$, four hours). Excess glutaraldehyde was absorbed with filter paper and the virus-seeded grid was air-dried in a biosafety cabinet overnight. Negative staining was performed by utilizing $2 \%$ phosphotungstic acid (EMS, USA) with a one-minute incubation before observation. STEM sample observation was conducted using a FEI Quanta 650 FEG (FEI, USA) electron microscope through the STEM mode $\left(1.5^{\circ} \mathrm{C}, 676 \mathrm{psi}, 30 \mathrm{kV}\right)$ with MAPS software. ${ }^{28}$

Reverse transcription-polymerase chain reaction (RT-PCR) and gel electrophoresis

Identification of SARS-CoV-2 virus culture was performed by total RNA extraction utilizing Trizol reagent (Thermo Fisher, USA) according to the manufacturer's protocol. A Qubit ${ }^{\mathrm{TM}}$ RNA BR Assay Kit (Thermo Fisher Scientific, USA) with a Qubit ${ }^{\mathrm{TM}}$ fluorometer was used according to the kit manual. ${ }^{29}$ RT-PCR was performed from extracted RNA samples utilizing the Goscript ${ }^{\circledR}$ RT-PCR system (Promega, USA) with SARS-CoV-2 receptor-binding domain spike gene primers adopted from previous studies (forward: 5'-CCACAGACACTTGAGATTC- $3^{\prime}$ and reverse: $5^{\prime}$-GCAACT GAATTTTCTGCACCA-3') and according to supplied protocol by Lau et al. ${ }^{30}$

Conventional PCR was performed from RT-PCR cDNA using the previously described primer with GoTaq ${ }^{\circledR}$ green master mix (Promega, USA) in a Thermal Cycler XP machine (Bioer Technology, China). Conventional PCR conditions were conducted through initial denaturation $\left(95^{\circ} \mathrm{C}\right.$, five minutes), amplification $\left(45\right.$ cycles of ten seconds, $\left.95^{\circ} \mathrm{C}\right)$, denaturation (ten seconds, $62^{\circ} \mathrm{C}$ ) annealing, (ten seconds, $72^{\circ} \mathrm{C}$ ) elongation, final elongation $\left(72^{\circ} \mathrm{C}\right.$, five minutes), and PCR reaction termination $\left(4^{\circ} \mathrm{C}, 30\right.$ minutes $)$. PCR products were detected by performing agarose gel electrophoresis in $2 \%$ agarose gel (INTRON Biotechnology, South Korea) in 0.5x Tris-Boric-EDTA (TBE) Buffer (BIOWORLD, USA) with 110 volts for 60 minutes, the DNA band was stained with ethidium bromide (TCI, Japan), and visualized through the Gel Doc XR+ gel documentation system (Bio-Rad, USA). The PCR product length was confirmed with Image Lab software for PC version 6.1 (SOFT-LIT-170-9690-ILSPC-V-6-1, Bio-Rad Laboratories Inc, Hercules, California, US, https:/www.bio-rad.com/en-id/product/image-lab-software?ID=KRE6P5E8Z) in alignment with a Thermal Cycler XP machine (Roche, USA). ${ }^{31,32}$

\section{Whole genome sequencing}

Whole genome sequencing protocol was performed by targeted sequencing after gene amplification using ARTIC V3 primer sets RT-PCR before proceeding to PCR clean up, and processed with Nanopore sequencing kits in the GRIDION platform, according to provided protocols supplied with the kits. ${ }^{33}$ Whole-genome sequencing was performed 
by Genetika Science Indonesia Ltd through EPI2ME Labs software version 21.05 (https://labs.epi2me.io/wfindex) and trimming through Medaka software version 1.3.4 (https://nanoporetech.github.io/medaka/). Gene analysis was performed by RAMPART software version 1.7.1 (https://artic.network/ncov-2019/ncov2019-using-rampart.html) for mutation analysis and identification of the spike gene and the Wuhan $\mathrm{Hu}-1$ as the reference sequence. ${ }^{34}$

Immunocytochemistry

Staining of Vero E6 SARS-CoV-2 infected cells were performed with immunized rabbit antibody serum, and visualization with diaminobenzidine (DAB) was performed with horseradish peroxidase (HRP) conjugated anti-rabbit IgG. Unspecific binding blocking was performed with $0.5 \%$ bovine serum albumin. The positive infected cells that were stained brown were observed by an inverted light microscope (Nikon TMS, Japan). ${ }^{35}$

\section{Western blot analysis}

Viral protein was extracted from infected Vero E6 SARS-CoV-2 culture by RIPA buffer (ThermoFisher Scientific, US) and PMSF extraction (Sigma-Aldrich, US). The sample was centrifuged at $3000 \times \mathrm{g}$ at $4{ }^{\circ} \mathrm{C}$ for one hour, and the samples were subjected to polyacrylamide gel electrophoresis (PAGE).

Samples were diluted and mixed with a Laemmli loading solution (Bio-Rad Laboratories Inc, US) and were denatured at $100^{\circ} \mathrm{C}$ for five minutes before loading on the polyacrylamide gel. Viral proteins were separated on $12 \%$ gradient polyacrylamide gels. The transfer of proteins to the PVDF membrane (Sigma-Aldrich, US) was performed with a TransBlot Turbo system (Bio-Rad Laboratories Inc, US) for seven minutes. ${ }^{36}$

Western blot was performed by using antibody serum from an immunized rabbit with visualization and with HRPconjugated anti-rabbit IgG polyclonal antibody with 1:10.000 concentration (Cat. no. 611-103-122, Rockland, USA) and DAB (Rockland, USA). A comparison of the western blot was made with convalescent serum that was collected from a volunteer COVID-19 convalescent subject with visualization by HRP-conjugated anti-human IgG polyclonal antibody with 1:10.000 concentration (Cat. no. 611-103-123, Rockland, USA) and DAB with 1X concentration (DAB-10, Rockland, USA). This human serum was used to demonstrate human immune response to SARS-CoV-2.

\section{Ethics statement}

Ethical clearance for this study was approved by the Institutional Review Board of the Dr Soetomo General Hospital, Surabaya (IRB Number IRB00008635), Ethical Clearance No. 0099/LOE/301.4.2/VIII/2020. During hospitalization, the subject or subject's guardian was informed about the study and gave their written informed consent for participating in this study and use for publication.

\section{Results}

In this study, we conducted the characterization of SARS-CoV-2 East Java isolate, Indonesia. ${ }^{37}$

\section{Virus isolation and culture}

SARS-CoV-2 CPE appeared in the form of rounding, elevation, and detachment of Vero E6 monolayer cell culture as reported previously. ${ }^{38}$ Virus passage was performed periodically until stable cytopathic effect patterns were established (5-6 days' interval) (see Figure 1).

\section{Growth characteristics and viral morphology}

Growth characteristics suggested a more adapted virus culture along with the blind passage progression and intervals with shorter CPE formation times. Moreover, TICD50 evaluation of \#35 isolate through plaque forming assay and Reed and Muench method showed $10^{13.76}$ TICD50.

\section{Scanning transmission electron microscopy}

FEI Quanta 650 FEG electron microscopy was performed in low vacuum SEM mode (80 Pa; $10 \mathrm{kV})$ at $80,000 \times$ magnification, and MAPS (Modular Automated Processing System) software observation was able to find several ovoidshaped multilobulated viral particles that were observed in SEM, with an estimated diameter ranging from 125.8-199.1 $\mathrm{nm}$ between filter membrane fibers. Further analysis in STEM showed SARS-CoV-2 viral particles with its surface spike proteins and internal diameter ranging from 120-200 nm (see Figure 2).

\section{Reverse transcription-polymerase chain reaction (RT-PCR)}

The visualization of a 398-base pair size band fragment of Receptor Binding Domain (RBD) sequences confirmed SARSCoV-2 presence. (Roche, USA) (see Figure 3 and Raw RT-PCR Results of SARS-COV-2 ${ }^{39}$ ). 


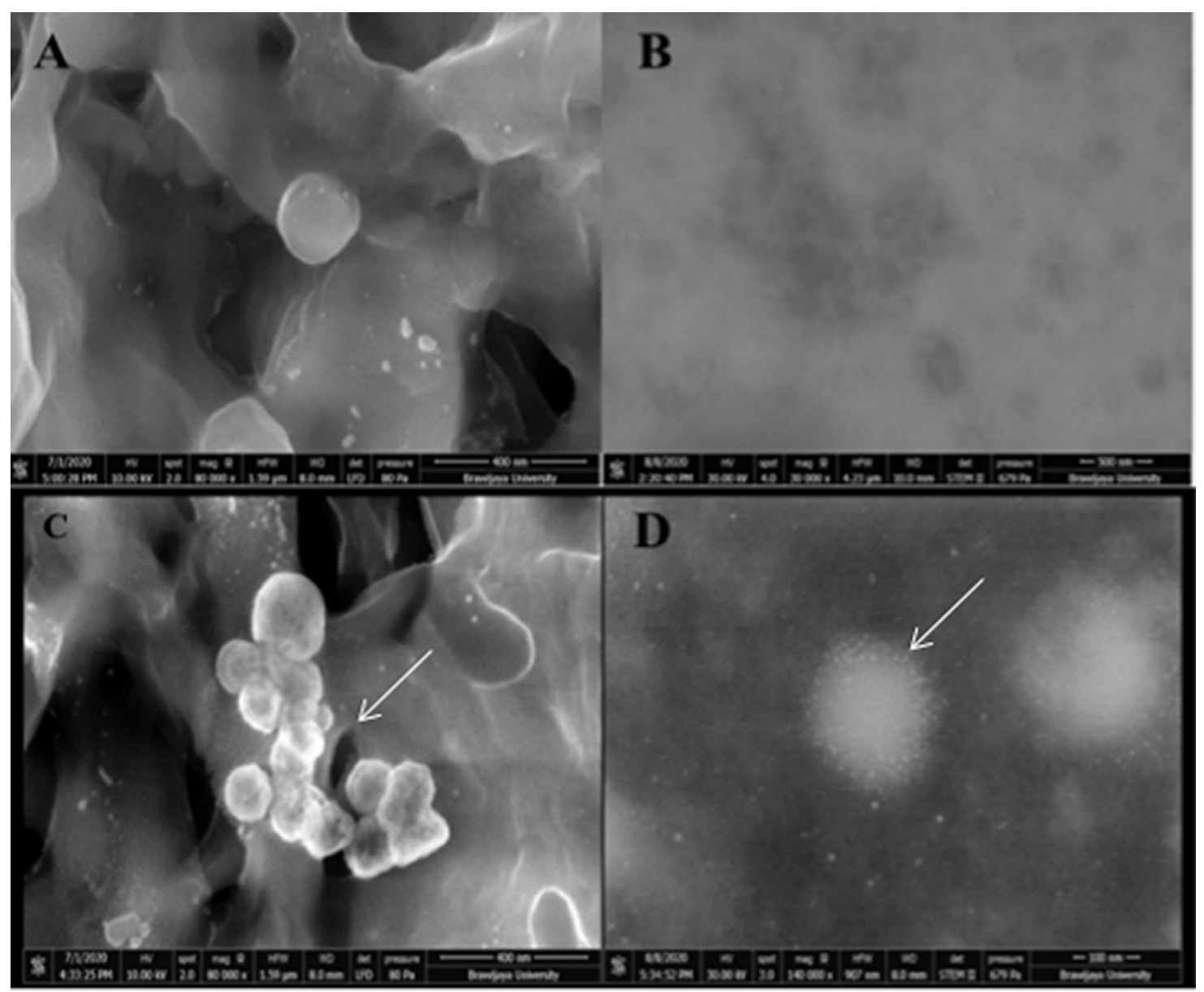

Figure 2. The result of scanning transmission electron microscopy (STEM) (A, B) uninfected cells medium acted as a blank control; (C, D) the morphology of severe acute respiratory syndrome coronavirus 2 (SARS-CoV-2) infected patients under scanning electron microscopy (SEM) $80,000 \times$ and scanning transmission electron microscopy (STEM) (FEI Quanta 650 FEG (FEI, USA).

\section{Spike gene analysis}

Spike gene analysis of three isolates from three patients found that only the D614G mutation was detected among the isolates, although in \#35 isolates D215Y and E484D mutations were also present. Based on whole genome analysis, those three isolates were included in clade 20A, and two isolates were included in lineage B.1.6, with one isolate belonging to lineage B.1.4.7 (Table 1).

\section{Isolation and characterization of protein immunogenic of SARS-CoV-2}

Immunocytochemistry staining suggested that antibody serum from immunized rabbit and human natural infection serum could detect SARS-CoV-2 infected cells in virus culture, indicated by brown stained cells that were observed in lightinverted microscopy with 100x magnification (Nikon TMS, Tokyo, Japan) (see Figure 4).

Comparison of western blot staining with antibody serum from immunized rabbit and human natural infection serum that was collected from a volunteer COVID-19 convalescent subject showed several main immunogenic proteins that were detected, including spike glycoprotein $(\mathrm{S})$, nucleocapsid protein $(\mathrm{N})$, membrane glycoprotein $(\mathrm{M})$, accessory $3 \mathrm{a}$ protein, and envelope protein (E). Both western blot comparisons between rabbit antibody serum and human convalescent serum from the second wave of COVID-19 in Surabaya showed a relatively similar protein immunogenic capacity (see Figure 5). ${ }^{37,40}$

\section{Discussion}

In this study, SARS-CoV-2 isolation was achieved by inoculation in Vero E6 cells and serial blind passages. Observation of phase contrast microscopy suggested CPE with a characteristic of rounding, syncytium formation, and cell detachment 


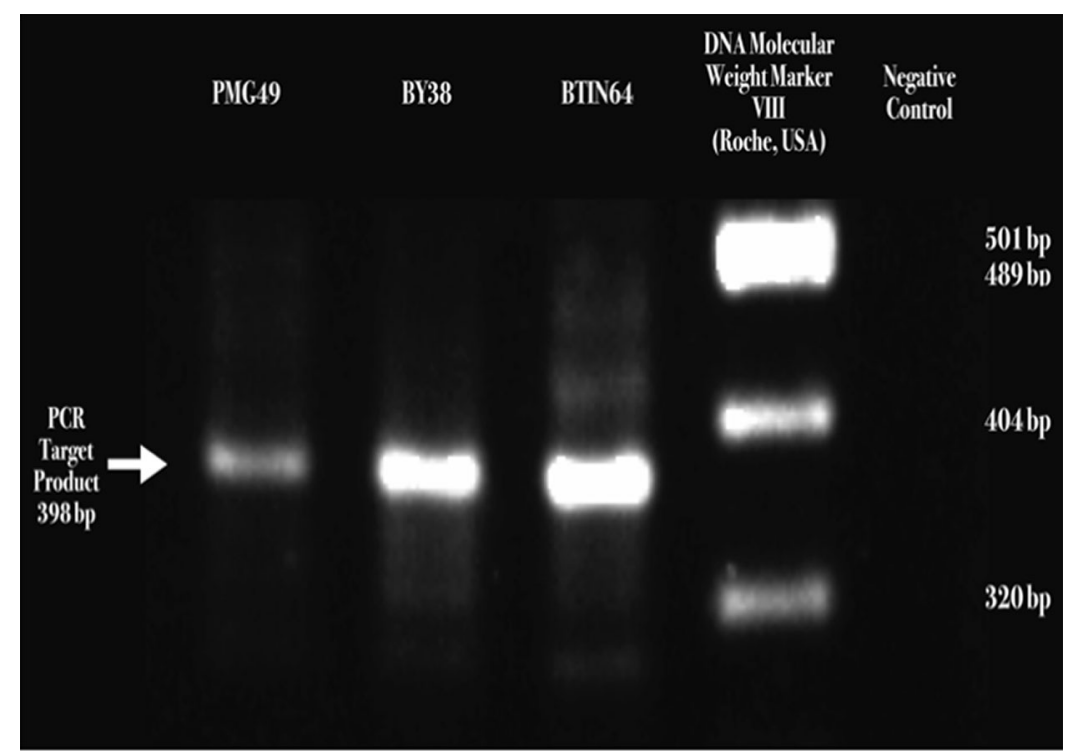

Figure 3. (A) Severe acute respiratory syndrome coronavirus 2 (SARS-CoV-2) S1/S2 cleavage site Receptor Binding Domain (RBD) detected by two-step reverse transcription-polymerase chain reaction (RT-PCR), DNA electrophoresis ethidium bromide staining, and visualized through the Gel Doc XR+ gel documentation system (Bio-Rad, USA).

Table 1. Isolate's lineage, clade, passage, amino acid mutation, reference sequence, and accession number.

\begin{tabular}{|c|c|c|c|c|c|c|c|c|}
\hline No & Isolates & Lineage & Clade & Passage & $\begin{array}{l}\text { Amino } \\
\text { Acid } \\
\text { Mutation }\end{array}$ & $\begin{array}{l}\text { Wuhan } \\
\text { (Refseq) }\end{array}$ & $\begin{array}{l}\text { GISAID } \\
\text { Accession ID }\end{array}$ & $\begin{array}{l}\text { NCBI } \\
\text { Accession } \\
\text { ID }\end{array}$ \\
\hline 1 & $35-A$ & B.1.6 & $20 \mathrm{~A}$ & 2 & $\begin{array}{l}\text { N: D128Y } \\
\text { ORF1b: } \\
\text { P314L, } \\
\text { V345L, } \\
\text { N1047D } \\
\text { ORF3a: } \\
\text { Q57H } \\
\text { ORF8: } \\
\text { G66X, } \\
\text { K68X } \\
\text { S: D215Y, } \\
\text { E484D, } \\
\text { D614G }\end{array}$ & $\begin{array}{l}\text { N: D128D } \\
\text { ORF1b: } \\
\text { P314P, } \\
\text { V345V, } \\
\text { N1047N } \\
\text { ORF3a: } \\
\text { Q57Q } \\
\text { ORF8: } \\
\text { G66G, } \\
\text { K68K } \\
\text { S: D215D, } \\
\text { E484E, } \\
\text { D614D }\end{array}$ & EPI_ISL_1364466 & MZ026853 \\
\hline 2 & BY38 & B.1.4.7 & $20 \mathrm{~A}$ & 15 & $\begin{array}{l}\text { ORF1b: } \\
\text { P218L, } \\
\text { P314L } \\
\text { ORF3a: } \\
\text { Q57H } \\
\text { S: D614G }\end{array}$ & $\begin{array}{l}\text { ORF1b: } \\
\text { P218P, } \\
\text { P314P } \\
\text { ORF3a: } \\
\text { Q57Q } \\
\text { S: D614D }\end{array}$ & EPI_ISL_1366083 & MZ026854 \\
\hline 3 & BTIN64 & B.1.6 & $20 \mathrm{~A}$ & 15 & $\begin{array}{l}\text { ORF1b: } \\
\text { P314L } \\
\text { S: D614G }\end{array}$ & $\begin{array}{l}\text { ORF1b: } \\
\text { P314P } \\
\text { S: D614D }\end{array}$ & EPI_ISL_1366238 & MZ026855 \\
\hline
\end{tabular}

with plaque formation. ${ }^{26}$ Evaluation during virus passage exhibited a shorter time for developing CPE in line with increasing passage numbers that indicated a more adapted virus culture. The serial passage of virus in the culture exhibit with shorter CPE formation indicated increases in virus titers, adaptation, and more virus replication efficiency. ${ }^{41}$

SARS-CoV-2 infection was confirmed by SEM, STEM, and RT-PCR examination. SEM observation showed a threedimensional structure of viral particles without spike protein visualization with a viral particle diameter that was in line with previously reported cases. STEM observation showed cross-sectional images of viral particle structure, with spike 

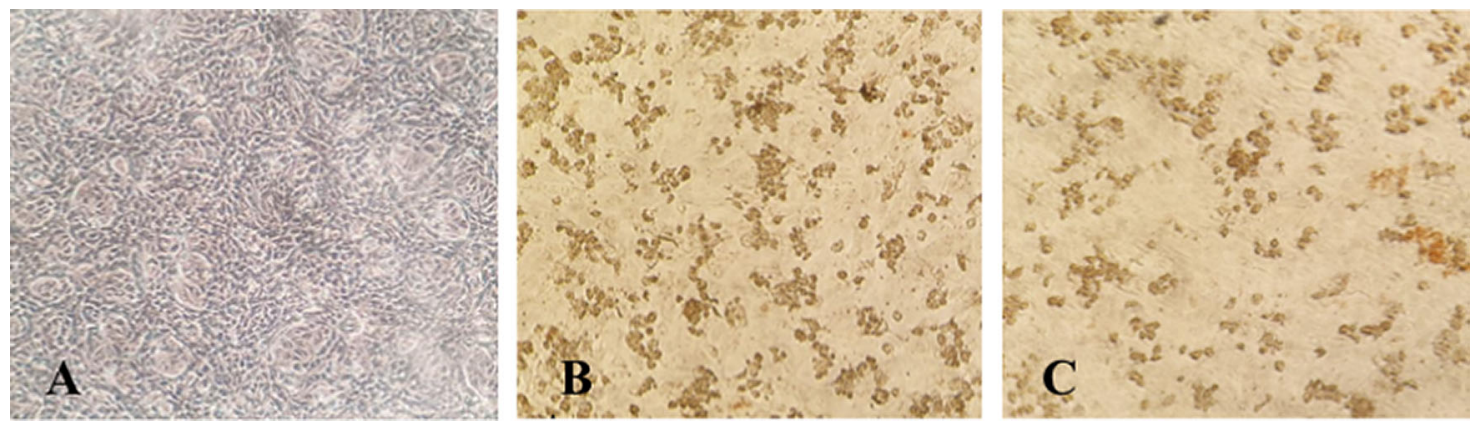

Figure 4. Severe acute respiratory syndrome coronavirus 2 (SARS-CoV-2) Vero E6 infected cells, immunocytochemistry using (A) uninfected Vero E6 cells as control; (B) rabbit antibody serum, (C) human antibody serum $(100 \times$ magnification $)$.
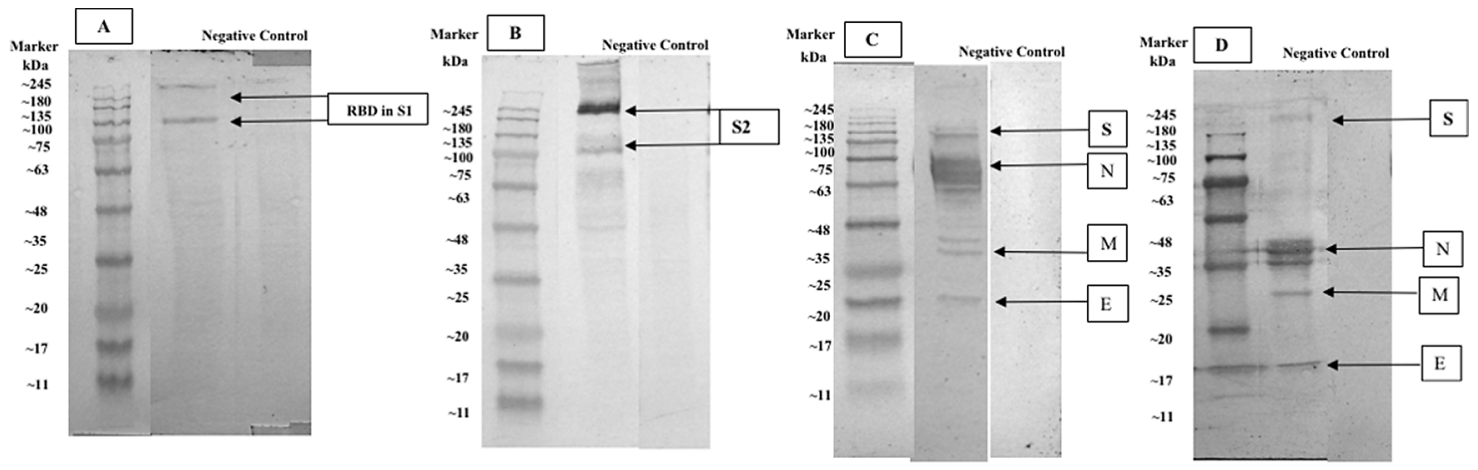

Figure 5. Severe acute respiratory syndrome coronavirus 2 (SARS-CoV-2) western blot staining with anti-SARSCoV-2 Receptor Binding Domain (RBD) monoclonal antibody for detecting S1 protein (MAB10540, RnD System) (8\% gel); (A): western blot staining with anti-SARS-CoV-2 S2 monoclonal antibody (MAB10557, RnD System) (8\% gel); (B): western blot staining with rabbit antibody serum (12\% gel); (C): western blot staining with human convalescent serum from the COVID-19 infection ( $8 \% \mathrm{gel}$ ); (D): (S) labeled for spike protein, (N) labeled for nucleoprotein protein, (M) labeled for membrane protein, (E) labeled for envelope protein.

protein visualization with a viral particle diameter relatively similar to a previous study that reported SARS-CoV-2 morphology using transmission electron microscope (TEM). ${ }^{26}$ However, interestingly, in this study, we found a rounded multilobulated SARS-CoV-2 viral particle structure (pleomorphic). SEM could detect a viral particle structure that was trapped in the filter fibers. However, the visualization was limited in the three-dimensional structure and could be biased. Fortunately, with STEM, the protein structure of the SARS-CoV-2 spike protein could be visualized more clearly than with SEM. In addition, adequate viral particle visualization enables viral particle internal diameter measurement. The confirmation of SARS-CoV-2 was done by a RT-PCR that detected the SARS-CoV-2 RBD that is located in the S1 subunit of the SARS-CoV-2 spike protein. ${ }^{23}$ Thus, the analysis of the SARS-CoV-2 spike gene shows the mutation of D614G that increases SARS-CoV-2 infectivity, whereas the E484D mutation was correlated with human immune serum neutralization resistance. ${ }^{21}$ Whole genome sequence analysis suggested that three isolates were included in clade $20 \mathrm{~A}$, and two isolates were included in lineage B.1.6, with one isolate belonging to lineage B.1.4.7. Lineage B.1 is the most abundant lineage that circulates in the environment. Evaluation of genetic stability could be evaluated during virus passage in the in vitro setting, as it is reported that genetic mutation may also occur besides natural infections and transmission. $^{42}$

SARS-CoV-2 infected Vero E6 cells showed a brown color as a positive marker, detected by means of immunized rabbit serum antibody and human natural infection serum antibody immunocytochemistry. Based on this result, evaluation of virus infectivity could be done. ${ }^{3}$ The comparison between the western blot analysis with immunized rabbit serum antibody and human natural infection serum may suggest that immune response towards SARS-CoV-2 infection tends to be relatively similar. Therefore, these results imply that SARS-CoV-2 immunogenic proteins may be suitable with a natural infection immune response. 
Western blot examination suggested that the main protein of SARS-CoV-2, which consisted of S, N, M, accessory 3a, and E proteins, showed that these proteins possessed immunogenic capability. ${ }^{3}$ Yet, the main protein that plays an important role in SARS-CoV-2 infection, especially in the binding-to-host cells through ACE2 receptors, is spike protein. ${ }^{4}$ The binding of antibodies to this SARS-CoV-2 main protein could mediate a SARS-CoV-2 immune response and possibly provide immune protection towards COVID-19.

\section{Conclusion}

Based on molecular characterization and immunogenicity of SARS-CoV-2 East Java, Indonesia showed high titer and it has mutation in some regions. Further study is still required to examine the genetic and immunogenic stability for seed vaccine exploration and it requires more investigation and clinical validation.

\section{Data availability}

Underlying data

Figshare: Underlying data for 'Characterization of SARS-CoV-2 East Java isolate, Indonesia', https://doi.org/10.6084/ m9.figshare.14703567.v1. ${ }^{37}$

This project contains the following underlying data:

'Severe acute respiratory syndrome coronavirus 2 (SARS-CoV-2) western blot staining with anti-severe acute respiratory syndrome coronavirus 2 (SARS-CoV-2) Receptor Binding Domain (RBD) monoclonal antibody for detecting S1 protein'

- Figure 5A. tiff

- Figure 5B. tiff

- Figure 5C. tiff

- $\quad$ Figure 5D. tiff

Figshare: https://doi.org/10.6084/m9.figshare.14703579.v1. ${ }^{39}$

This project contains the following underlying data:

'Raw RT-PCR Results of SARS-COV-2'

- Raw PCR.tiff

Figshare: https://doi.org/10.6084/m9.figshare.14703582.v1. ${ }^{40}$

This project contains the following underlying data:

'Gels for the Western blot (Raw) Severe acute respiratory syndrome coronavirus 2 (SARS-CoV-2) western blot staining with anti-Severe acute respiratory syndrome coronavirus 2 (SARS-CoV-2) Receptor Binding Domain (RBD) monoclonal antibody for detecting S1 protein'

- Raw WB A.tiff

- Raw WB B.tiff

- Raw WB C.tiff

- Raw WB D.tiff

Data are available under the terms under the terms of the Creative Commons Attribution 4.0 International license (CCBY 4.0). 


\section{Consent}

Written informed consent for publication of the patients' details was obtained from the patients.

\section{Acknowledgements}

The authors thank the entire staff of Dr Soetomo General Hospital and Airlangga University for providing the access and facilities to perform this study. We thank Dr Rer. Nat. Setyawan Purnomo Sakti, M.Eng., and Nike as staff of Electron Microscopy Unit, Brawijaya University, Malang, Indonesia, for the assistance in electron microscopy. We thank Abdul Hadi Furqoni, M.Si. for the involvement in this study. We thank Suryo Kuncorojakti, Ph.D and Dr. Alexander Patera Nugraha for the discussion of this study. We thank the entire subject involved in this study for participating in research and development of COVID-19 management.

1. MacKenzie JS, Smith DW: COVID-19: A novel zoonotic disease caused by a coronavirus from China: What we know and what we don't. Microbiol Aust. 2020; 41: 45-50.

PubMed Abstract | Publisher Full Text | Free Full Text

2. Pal M, Berhanu G, Desalegn C, et al.: Severe Acute Respiratory Syndrome Coronavirus-2 (SARS-CoV-2): An Update. Cureus. 2020; 12: e7423.

PubMed Abstract | Publisher Full Text | Free Full Text

3. Zhang $X-Y$, Guo J, Wan $X$, et al.: Biochemical and antigenic characterization of the structural proteins and their posttranslational modifications in purified SARS-CoV-2 viral particles of an inactivated vaccine candidate. Emerg Microbes Infect. 2020; 9: 2653-2662.

PubMed Abstract | Publisher Full Text | Free Full Text

4. Li M-Y, Li L, Zhang Y, et al.: Expression of the SARS-CoV-2 cell receptor gene ACE2 in a wide variety of human tissues. Infect Dis Poverty. 2020; 9: 45

PubMed Abstract | Publisher Full Text | Free Full Text

5. Korber B, Fischer WM, Gnanakaran S, et al.: Tracking changes in SARS-CoV-2 Spike: evidence that D614G increases infectivity of the COVID-19 virus. Cell. 2020

PubMed Abstract | Publisher Full Text | Free Full Text

6. Plante JA, Liu Y, Liu J, et al.: Spike mutation D614G alters SARS-CoV2 fitness. Nature. 2020

PubMed Abstract | Publisher Full Text | Free Full Text

7. Wang P, Nair MS, Liu L, et al.: Antibody Resistance of SARS-CoV-2 Variants B.1.351 and B.1.1.7. Nature. 2021: 2021.01.25.428137. PubMed Abstract | Publisher Full Text

8. Zhou $P$, Lou YX, Wang XG, et al.: A pneumonia outbreak associated with a new coronavirus of probable bat origin. Nature. 2020; 579: 270-273.

PubMed Abstract | Publisher Full Text | Free Full Text

9. Cucinotta D, Vanelli M: WHO Declares COVID-19 a Pandemic. Acta Biomed. 2020; 91: 157-160.

PubMed Abstract | Publisher Full Text | Free Full Text

10. Wang $Y$, Wang $Y$, Chen $Y$, et al.: Unique epidemiological and clinical features of the emerging 2019 novel coronavirus pneumonia (COVID-19) implicate special control measures. IMed Virol. 2020; 92: 568-576.

PubMed Abstract | Publisher Full Text | Free Full Text

11. Gupta A, Madhavan MV, Sehgal K, et al.: Extrapulmonary manifestations of COVID-19. Nat Med. 2020; 26: 1017-1032. PubMed Abstract | Publisher Full Text

12. Oran DP, Topol EJ: Prevalence of Asymptomatic SARS-CoV2 Infection: A Narrative Review. Ann Intern Med. 2020; 173. 362-367.

PubMed Abstract | Publisher Full Text | Free Full Text

13. WHO: Coronavirus Disease 2019 (COVID-19) Indonesia Situation Report - 1. Jakarta: 2020.

14. Setiati S, Azwar MK: COVID-19 and Indonesia. Acta Med Indones. 2020; 52: 84-89. PubMed Abstrac

15. WHO: Coronavirus Disease 2019 (COVID-19) Indonesia Situation Report - 26. Jakarta: 2020.

16. United Nation Department of Economic and Social Affairs PD: World Population Prospects 2019: Highlights (ST/ESA/SER.A/423). New York: United Nations; 2019.
17. Djalante R, Lassa J, Setiamarga D, et al.: Review and analysis of current responses to COVID-19 in Indonesia: Period of January to March 2020. Prog Disaster Sci. 2020; 6: 100091. Publisher Full Text

18. Anderson RM, Heesterbeek $\mathrm{H}$, Klinkenberg $\mathrm{D}$, et al.: How will country-based mitigation measures influence the course of the COVID-19 epidemic? Lancet. 2020; 395: 931-934. PubMed Abstract | Publisher Full Text | Free Full Text

19. Hidayat R, Aini N, Ilmi AFN, et al.: Trace, and Treatment Strategy to Control COVID-19 Infection Among Hospital Staff in a COVID-19 Referral Hospital in Indonesia. Acta Med Indones. 2020; 52: 206-213. PubMed Abstract

20. Xu S, Li Y: Global coalition to accelerate COVID-19 clinical research in resource-limited settings. Lancet. 2020; 395: 1322-1325.

PubMed Abstract | Publisher Full Text | Free Full Text

21. Elbe S, Buckland-Merrett G: Data, disease and diplomacy: GISAID's innovative contribution to global health. Glob Chall. 2017: 1: 33-46.

PubMed Abstract | Publisher Full Text | Free Full Text

22. Harcourt J, Tamin A, Lu X, et al.: Severe Acute Respiratory Syndrome Coronavirus 2 from Patient with Coronavirus Disease, United States. Emerg Infect Dis. 2020; 26: 1266-1273. PubMed Abstract | Publisher Full Text | Free Full Text

23. Lauring AS, Hodcroft EB: Genetic Variants of SARS-CoV-2-What Do They Mean? JAMA. 2021; 2: 27-29. PubMed Abstract | Publisher Full Text

24. Turner P, Po L, Turner C, et al.: Detection of Respiratory Viruses by PCR Assay of Nasopharyngeal Swabs Stored in Skim MilkTryptone-Glucose-Glycerol Transport Medium: Table 1. J Clin Microbiol. 2011; 49: 2311-2313. PubMed Abstract | Publisher Full Text | Free Full Text

25. Kaufer AM, Theis T, Lau KA, et al.: Laboratory biosafety measures involving SARS-CoV-2 and the classification as a Risk Group 3 biological agent. Pathology. 2020; 52: 790-795. PubMed Abstract | Publisher Full Text | Free Full Text

26. Park WB, Kwon NJ, Choi SJ, et al.: Virus isolation from the first patient with SARS-CoV-2 in Korea.J Korean Med Sci. 2020; 35: 10-14. PubMed Abstract | Publisher Full Text | Free Full Text

27. Public Health England: Preparation of Coated Grids for Electron Microscopy. UK Stand Microbiol Investig. 2014: 12

28. Möller L, Holland G, Laue M: Diagnostic Electron Microscopy of Viruses With Low-voltage Electron Microscopes. J Histochem Cytochem. 2020; 68: 389-402.

PubMed Abstract | Publisher Full Text

29. Falzone L, Musso N, Gattuso G, et al.: Sensitivity assessment of droplet digital PCR for SARS-CoV-2 detection. Int J Mol Med. 2020; 46: 957-964.

PubMed Abstract | Publisher Full Text | Free Full Text

30. Lau S-Y, Wang P, Mok BW-Y, et al.: Attenuated SARS-CoV-2 variants with deletions at the S1/S2 junction. Emerg Microbes Infect. 2020; 9: 837-842.

PubMed Abstract | Publisher Full Text | Free Full Text

31. Son HA, Hang DTT, Thuan ND, et al.: A simple method for detection of a novel coronavirus (SARS-CoV-2) using one-step RT-PCR followed by restriction fragment length polymorphism. J Med 
Virol. 2020; 92: 2839-2846.

PubMed Abstract | Publisher Full Text | Free Full Text

32. González-González E, Trujillo-De Santiago G, Lara-Mayorga IM, et al.: Portable and accurate diagnostics for COVID-19: Combined use of the miniPCR thermocycler and a well-plate reader for SARS-CoV-2 virus detection. PLoS One. 2020; 15: 1-13. PubMed Abstract | Publisher Full Text | Free Full Text

33. Li J, Wang $\mathrm{H}$, Mao L, et al.: Rapid genomic characterization of SARS-CoV-2 viruses from clinical specimens using nanopore sequencing. Sci Rep. 2020; 10: 1-10.

PubMed Abstract | Publisher Full Text | Free Full Text

34. Mapleson D, Drou N, Swarbreck D: RAMPART: a workflow management system for de novo genome assembly. Bioinformatics. 2015; 31: 1824-1826. PubMed Abstract | Publisher Full Text | Free Full Text

35. Zhang $H$, Zhou $P$, Wei $Y$, et al.: Histopathologic Changes and SARS-CoV-2 Immunostaining in the Lung of a Patient With COVID-19. Ann Intern Med. 2020; 172: 629-632. PubMed Abstract | Publisher Full Text | Free Full Text

36. Seenichamy A, Bahaman AR, Mutalib AR, et al.: Production and characterization of a polyclonal antibody of Anti-rLipL21-IgG against leptospira for early detection of acute leptospirosis. Biomed Res Int. 2014; 2014.

PubMed Abstract | Publisher Full Text | Free Full Text

37. Rantam: FA Severe acute respiratory syndrome coronavirus 2 (SARS-CoV-2) western blot staining with anti-Severe acute respiratory syndrome coronavirus 2 (SARS-CoV-2) Receptor Binding Domain (RBD) monoclonal antibody for detecting S1 protein. Figshare. 2021.

Publisher Full Text

38. Kim JM, Chung YS, Jo HJ, et al.: Identification of coronavirus isolated from a patient in Korea with covid-19. Osong Public Heal Res Perspect. 2020; 11: 3-7.

PubMed Abstract | Publisher Full Text | Free Full Text

39. Rantam: FA Raw RT-PCR Results of SARS-COV-2. Figshare. 2021. Publisher Full Text

40. Rantam: FA Gels for the Western blot (Raw) Severe acute respiratory syndrome coronavirus 2 (SARS-CoV-2) western blot staining with anti-Severe acute respiratory syndrome coronavirus 2 (SARS-CoV-2) Receptor Binding Domain (RBD) monoclonal antibody for detecting S1 protein. Figshare. 2021. Publisher Full Text

41. Kumar N, Barua S, Riyesh T, et al.: Complexities in isolation and purification of multiple viruses from mixed viral infections: Viral interference, persistence and exclusion. PLoS One. 2016; 11: $1-24$.

PubMed Abstract | Publisher Full Text | Free Full Text

42. Sasaki M, Uemura K, Sato A, et al.: SARS-CoV-2 variants with mutations at the S1/S2 cleavage site are generated in vitro during propagation in TMPRSS2-deficient cells. PLOS Pathog. 2021; 17: 1-17.

PubMed Abstract | Publisher Full Text | Free Full Text 


\section{Open Peer Review}

\section{Current Peer Review Status:}

\section{Version 1}

Reviewer Report 29 September 2021

https://doi.org/10.5256/f1000research.56490.r93419

(C) 2021 Derkho $\mathbf{M}$. This is an open access peer review report distributed under the terms of the Creative Commons Attribution License, which permits unrestricted use, distribution, and reproduction in any medium, provided the original work is properly cited.

\section{Marina Derkho}

South Ural State Agrarian University, Troitsk, Russian Federation

1. The topic of the article is very relevant at the present time. Therefore, when describing the methods, it is desirable to give a scheme of research design.

2. Statistical analysis may not be available in this article.

3. In Figure 4, you can more accurately indicate the presence of detected changes.

4. The conclusions do not reflect the presented data

Is the work clearly and accurately presented and does it cite the current literature? Yes

Is the study design appropriate and is the work technically sound?

Yes

Are sufficient details of methods and analysis provided to allow replication by others? Partly

If applicable, is the statistical analysis and its interpretation appropriate? Not applicable

Are all the source data underlying the results available to ensure full reproducibility? Partly

Are the conclusions drawn adequately supported by the results? No 
Competing Interests: No competing interests were disclosed.

I confirm that I have read this submission and believe that I have an appropriate level of expertise to confirm that it is of an acceptable scientific standard, however I have significant reservations, as outlined above.

Reviewer Report 20 September 2021

https://doi.org/10.5256/f1000research.56490.r93422

(C) 2021 Valadas L. This is an open access peer review report distributed under the terms of the Creative Commons Attribution License, which permits unrestricted use, distribution, and reproduction in any medium, provided the original work is properly cited.

\section{Lidia Audrey Rocha Valadas}

University of Buenos Aires, Buenos Aires, Argentina

This is a interesting study that investigates and characterizes SARS-CoV-2 isolated from East Java, Indonesia. In general, the manuscript is well designed and and can be reproducible for others. The methods and results, specially, were very well conducted.

Some of my suggestions below:

I suggest a little change on the title, for example: Characterization of SARS-CoV-2 isolated in East Java-Indonesia.

I suggest a flowchart on the Methods-Subject characteristics.

It's missing the ethical aspects (approval number of the project). It's cited just the consent signed.

Please provide the limitations.

Is the work clearly and accurately presented and does it cite the current literature? Yes

Is the study design appropriate and is the work technically sound?

Yes

Are sufficient details of methods and analysis provided to allow replication by others? Yes

If applicable, is the statistical analysis and its interpretation appropriate? Not applicable

Are all the source data underlying the results available to ensure full reproducibility? Yes 
Are the conclusions drawn adequately supported by the results?

Yes

Competing Interests: No competing interests were disclosed.

Reviewer Expertise: Dentistry, Saliva, Biofilms

I confirm that I have read this submission and believe that I have an appropriate level of expertise to confirm that it is of an acceptable scientific standard.

Reviewer Report 16 September 2021

https://doi.org/10.5256/f1000research.56490.r87787

(C) 2021 Aulanni'am A. This is an open access peer review report distributed under the terms of the Creative Commons Attribution License, which permits unrestricted use, distribution, and reproduction in any medium, provided the original work is properly cited.

\section{Aulanni'am Aulanni'am}

Department of Biochemistry, Faculty of Mathematics and Natural Sciences, Universitas Brawijaya, Malang, Indonesia

This study showed the important result that can be studied by others. SARS-Cov2 isolate plays important roles for disease development so it will help for progressive effect prevention that lead to mortality. The technique applied in this work also reliable to follow in standard infectious laboratory. By identification of local isolates, it would be useful to identify disease transmission as well as the impact to disease progressive. They used standard method that can be followed by other researchers with the same objective

Is the work clearly and accurately presented and does it cite the current literature? Yes

Is the study design appropriate and is the work technically sound?

Yes

Are sufficient details of methods and analysis provided to allow replication by others? Yes

If applicable, is the statistical analysis and its interpretation appropriate? Partly

Are all the source data underlying the results available to ensure full reproducibility? No source data required

Are the conclusions drawn adequately supported by the results? Yes 
Competing Interests: No competing interests were disclosed.

Reviewer Expertise: Biochemistry, Molecular diagnostic, medical devices development, Biomedics I confirm that I have read this submission and believe that I have an appropriate level of expertise to confirm that it is of an acceptable scientific standard.

The benefits of publishing with F1000Research:

- Your article is published within days, with no editorial bias

- You can publish traditional articles, null/negative results, case reports, data notes and more

- The peer review process is transparent and collaborative

- Your article is indexed in PubMed after passing peer review

- Dedicated customer support at every stage

For pre-submission enquiries, contact research@f1000.com 